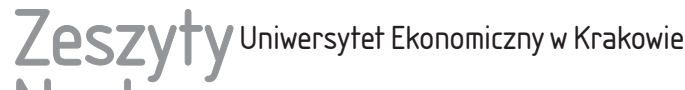 Naukowe
}

\section{Polityka bilansu banku centralnego a kurs walutowy}

\section{Streszczenie}

Kryzys finansowy zapoczątkowany na amerykańskim rynku nieruchomości spowodował wprowadzenie istotnych zmian w polityce pieniężnej, a jedna z najważniejszych z nich dotyczy polityki bilansu banku centralnego, w której dużą rolę odgrywa kwestia kursu walutowego. W artykule przedstawiono klasyfikację polityki bilansu banku centralnego z uwzględnieniem znaczenia, jakie w jej poszczególnych formach jest przypisywane kursowi walutowemu. Dokonano przeglądu literatury przedmiotu, w której analizowano wagę przypisywaną kursowi walutowemu w prowadzeniu polityki pieniężnej opartej na kształtowaniu wielkości oraz struktury bilansu. Poruszono również kwestie dotyczące kanałów transmisji polityki bilansu na kurs walutowy.

Słowa kluczowe: polityka bilansu banku centralnego, kurs walutowy, kryzys finansowy, dewaluacja.

Klasyfikacja JEL: O24, E58, E52.

\section{Wprowadzenie}

Pęknięcie bańki spekulacyjnej na amerykańskim rynku nieruchomości w 2007 r. zapoczątkowało kryzys finansowy, który objął całą światową gospodarkę. Jego skalę obrazuje odnotowany w 2009 r. spadek globalnego PKB, pierwszy od czasów II wojny światowej, wynoszący według danych Banku Światowego ok. $1,7 \%$. Władze monetarne stanęły przed wyzwaniami porównywalnymi 
jedynie z sytuacją związaną z wystąpieniem wielkiego kryzysu lat 30 . XX w. oraz okresem wzmożonych procesów inflacyjnych lat 70 .

W celu ograniczenia negatywnych społeczno-gospodarczych skutków kryzysu w znacznej części banków centralnych na świecie w ramach prowadzonej polityki pieniężnej zdecydowano się na zastosowanie niekonwencjonalnych środków, obawiano się bowiem, że standardowe działania będą niewystarczające. L.B. Smaghi (2009), członek zarządu Europejskiego Banku Centralnego, podczas wykładu w International Center for Monetary and Banking Studies w Genewie 28 kwietnia 2009 r. zauważył, że w tych nietypowych czasach konwencjonalne instrumenty polityki pieniężnej mogą okazać się niedostateczne do osiągnięcia celów stawianych przed bankami centralnymi. Na rozszerzenie zakresu stosowanych narzędzi polityki pieniężnej zdecydowały się m.in.: System Rezerwy Federalnej USA, Bank Anglii, EBC, Bank Japonii, Sveriges Riksbank (Szwecja) oraz Bank Danii.

Do najczęściej podejmowanych działań mających charakter niestandardowy zalicza się: zasilanie w płynność w trybie przetargu kwotowego z pełnym przydziałem, poszerzenie listy aktywów kwalifikowanych jako zabezpieczenie, zasilanie w płynność na dłuższy okres, zasilanie w płynność w walutach obcych oraz bezwarunkowy skup określonych papierów dłużnych. Za niekonwencjonalną politykę pieniężną można również uznać zapowiedź utrzymywania stopy procentowej na poziomie bliskim zera przez dłuższy czas (forward guidance) oraz obniżenie stopy procentowej do wartości bliskiej zeru (zero lower bound) (Rzońca 2014, s. 17). Ekonomiści zajmujący się analizowaniem wykorzystywania niekonwencjonalnych instrumentów polityki pieniężnej stosują różne klasyfikacje tych narzędzi. C. Borio oraz P. Disyatat (2009), analizując narzędzia polityki pieniężnej banków centralnych, także te niekonwencjonalne, wyróżnili dwa rodzaje prowadzonej polityki: politykę stopy procentowej oraz politykę bilansu banku centralnego.

Celem artykułu jest przedstawienie zagadnień dotyczących wpływu polityki bilansu banku centralnego na kształtowanie się kursu walutowego, dokonano więc przeglądu literatury przedmiotu z zakresu teoretycznych podstaw zależności występujących między strukturą bilansu banku centralnego a kursem walutowym. Analizę teoretyczną uzupełniono opisem studiów przypadku wybranych działań banków centralnych, związanych z omawianym problemem, istotnych w kontekście współczesnej polityki pieniężnej. W tej części badania wykorzystano dane statystyczne pochodzące z raportów banków centralnych. Poddano także analizie kwestię wykorzystywania pozycji bilansowych banku centralnego w celu kształtowania kursu walutowego w ramach polityki kursu walutowego prowadzonej przed kryzysem. Przedstawiono również zmiany dotyczące sum bilansowych wybranych banków centralnych będące rezultatem ich działań antykryzysowych. Dokonano ponadto przeglądu teorii ekonomicznych próbujących wyjaśnić zależności występujące pomiędzy wielkością bilansu banku centralnego a kształtowaniem się 
kursu walutowego, aby określić, w jakim stopniu taka polityka władz monetarnych może wpływać na kształtowanie się poziomu oraz zmienności kursu walutowego.

\section{Polityka bilansu banku centralnego}

Dokonując systematyzacji działań, jakie banki centralne podejmowały przed kryzysem finansowym lat 2007-2009 oraz w jego wyniku, C. Borio oraz P. Disyatat wyróżnili dwa rodzaje polityki władz monetarnych: politykę stopy procentowej (interest rate policy) oraz politykę bilansu banku centralnego (balance sheet policy). Polityka stopy procentowej była powszechnie stosowana przez banki centralne przed kryzysem i jest uważana za konwencjonalną. Polega na ogłaszaniu przez władze monetarne pożądanego poziomu stopy procentowej, a następnie wykorzystywaniu operacji zarządzających płynnością w celu osiągnięcia zakładanych wartości. Polityka bilansu banku centralnego polega natomiast „,na aktywnym wykorzystywaniu pozycji bilansu banku centralnego w celu bezpośredniego oddziaływania na ceny rynkowe oraz długookresową stopę procentową" (Borio i Disyatat 2009, s. 2). Jest ona prowadzona przez banki centralne w okresach kryzysowych, gdy wpływanie na długookresową stopę procentową poprzez kształtowanie początku krzywej dochodowości jest nieskuteczne. Właśnie dlatego liczba banków centralnych stosujących tę formę polityki znacznie wzrosła.

Ze względu na wpływ na strukturę bilansu sektora prywatnego oraz docelowy segment rynku można wyróżnić cztery podstawowe formy polityki bilansu (Borio i Disyatat 2009, s. 6-8). Pierwszą z nich jest polityka kursu walutowego (exchange rate policy). Polega ona na interweniowaniu przez bank centralny na rynku walutowym przez sprzedaż lub skup walut obcych za walutę krajową albo poprzez sprzedaż bądź zakup papierów wartościowych denominowanych w walutach obcych $^{1}$. Zwykle celem tych interwencji jest utrzymanie kursu waluty krajowej na poziomie, do którego zobowiązały się władze monetarne.

Drugą formą, jaką przyjmuje polityka bilansu, jest quasi-zarządzanie długiem publicznym (quasi-debt management policy) - jest to skupowanie przez bank centralny papierów dłużnych sektora publicznego (najczęściej obligacji rządowych) od sektora prywatnego, w literaturze przedmiotu określane również mianem luzowania ilościowego (quantitative easing), czego skutkiem jest zmiana struktury aktywów sektora prywatnego.

${ }^{1}$ J. Frankel (2014) sugerował, że działania polegające na przeprowadzeniu operacji kupna i sprzedaży papierów wartościowych denominowanych w walutach obcych powinny były zostać podjęte przez EBC w 2014 r. Na takie rozwiązanie zdecydował się Szwajcarski Bank Narodowy (Borio i Disyatat 2009, s. 17). 
Kolejnym sposobem aktywnego kształtowania bilansu banku centralnego jest prowadzenie polityki kredytowej (credit policy), co polega na podejmowaniu przez bank centralny prób zmiany warunków na rynku kredytów dla sektora prywatnego. W ramach polityki kredytowej podejmowane są następujące działania (Borio i Disyatat 2009, s. 6-8):

- zwiększenie zakresu akceptowanych zabezpieczeń kredytów oferowanych przez bank centralny,

- wydłużenie okresu kredytowania,

- rozszerzenie listy partnerów w programach kredytowych,

- skupowanie papierów wartościowych emitowanych przez sektor prywatny.

Ostatnia forma polityki bilansu banku centralnego, prowadzona kiedyś przez Bank Japonii (zob. Kimura i Small 2004), polega na ustanowieniu celu dotyczącego poziomu rezerw banków komercyjnych w banku centralnym, przy czym nie jest ważna struktura aktywów banku centralnego. Taki rodzaj działań jest określany mianem polityki rezerw bankowych.

\section{Polityka kursu walutowego}

Rozważania na temat polityki bilansu banku centralnego w kontekście kursu walutowego należy rozpocząć od zagadnień dotyczących właśnie polityki kursu walutowego. Po pierwsze, ze względu na to, że jest ona często stosowana, a po drugie, dlatego że w przeciwieństwie do innych rodzajów polityki bilansu bezpośrednio oddziałuje na rynek walutowy, kształtując kurs walutowy.

Analizując realizowanie przez banki centralne polityki kursu walutowego, R. Moreno (2005) wyróżnił trzy główne grupy celów interwencji walutowych o charakterze makroekonomicznym: 1) kontrolowanie inflacji oraz utrzymanie równowagi wewnętrznej, 2) utrzymanie równowagi zewnętrznej, wzrostu gospodarczego oraz efektywnej alokacji zasobów, 3) utrzymanie stabilności finansowej (zapobieganie kryzysom). Ich osiągnięciu ma służyć wyznaczenie celów szczegółowych, do których zalicza się:

- utrzymanie określonego kursu walutowego,

- zmniejszenie zmienności kursu walutowego (osiągane poprzez: symetryczne ograniczanie jego zmienności, zapobieganie nadmiernym ruchom, zapobieganie zbyt szybkim zmianom, utrzymywanie płynności na rynku walutowym),

- budowanie rezerw walutowych.

Nie oznacza to, że bank centralny nie może realizować kilku celów jednocześnie. Należy zauważyć, że w wypadku prawie $80 \%$ banków centralnych krajów rozwijających się powodem interwencji była chęć zmniejszenia presji spekulacyjnej (Mohanty 2013, s. 6). 
W kontekście polityki bilansu istotna jest również druga grupa celów interwencji walutowych, a w szczególności utrzymanie zaniżonego kursu waluty krajowej w ramach strategii uzależnienia wzrostu gospodarczego od eksportu. A. Brunet oraz J.P. Guichard (2011, s. 94-107) zauważyli, że jest to strategia merkantylistyczna, prowadząca do sytuacji, w której występują „kraje wierzyciele” i „kraje dłużnicy”. Według B. Bernankego (2005) dokonywanie przez niektóre państwa interwencji walutowych mających na celu powstrzymanie aprecjacji waluty krajowej w związku ze wspomnianą strategią było jedną z przyczyn tzw. globalnej nadwyżki oszczędności (global saving glut). W opinii byłego prezesa Systemu Rezerwy Federalnej USA „nawis oszczędności” tłumaczy również wystąpienie zjawiska określanego jako conundrum ${ }^{2}$ (Bernanke 2015). Niektórzy ekonomiści twierdzą, że był on także przyczyną kryzysu finansowego lat 2007-2009 (zob. Twardosz 2013), choć według C. Boria i P. Disyataty (2011) wątpliwe jest, aby nadwyżka oszczędności była głównym czynnikiem, który doprowadził do kryzysu.

Należy zauważyć, że jedną z przyczyn, dla których w wielu państwach rozwijających się zdecydowano się na akumulację rezerw walutowych (dokonując interwencji walutowych), był kryzys azjatycki z 1997 r. (zob. rys. 1). W jego rezultacie część państw Azji Południowo-Wschodniej musiała prosić instytucje międzynarodowe o pomoc finansową. Wyższy poziom rezerw walutowych ma więc stanowić dla nich bufor bezpieczeństwa (Bernanke 2005). Warto podkreślić, że w latach 2001-2007 rezerwy walutowe na świecie zwiększyły się ponad trzykrotnie i osiągnęły wartość 6,3 biliona USD (Borio, Gabriele i Heath 2008, s. 15). W sierpniu 2014 r. uzyskały one rekordowy poziom 12,03 biliona USD, czyli przekroczyły wartość 20\% kapitalizacji światowych giełd w tamtym okresie (Xie i Wong 2015).

W ramach dążenia do osiągnięcia zakładanych celów na rynku walutowym bank centralny może decydować się na różnego rodzaju interwencje. Na rys. 2 została przedstawiona ich klasyfikacja, przy czym wiersz drugi zawiera najczęściej uwzględniane kryteria podziału. Władze monetarne dokonują zwykle sterylizacji interwencji walutowych z wykorzystaniem odpowiednich operacji otwartego rynku. Mogą mieć one formę emisji papierów dłużnych banku centralnego (jak w wypadku Banku Korei) lub operacji typu repo i reverse repo (warunkowych) - takie rozwiązanie zostało zastosowane przez Bank Tajlandii, choć emituje on także bony pieniężne.

${ }^{2}$ Określenie conundrum (łamigłówka) dotyczy sytuacji, która miała miejsce w połowie ostatniego dziesięciolecia, kiedy pomimo podwyżek stóp procentowych wprowadzonych przez System Rezerwy Federalnej USA długoterminowe stopy procentowe na rynku amerykańskim nie uległy wzrostowi. Zostało ono użyte po raz pierwszy przez wieloletniego prezesa Systemu Rezerwy Federalnej USA A. Greenspana. 


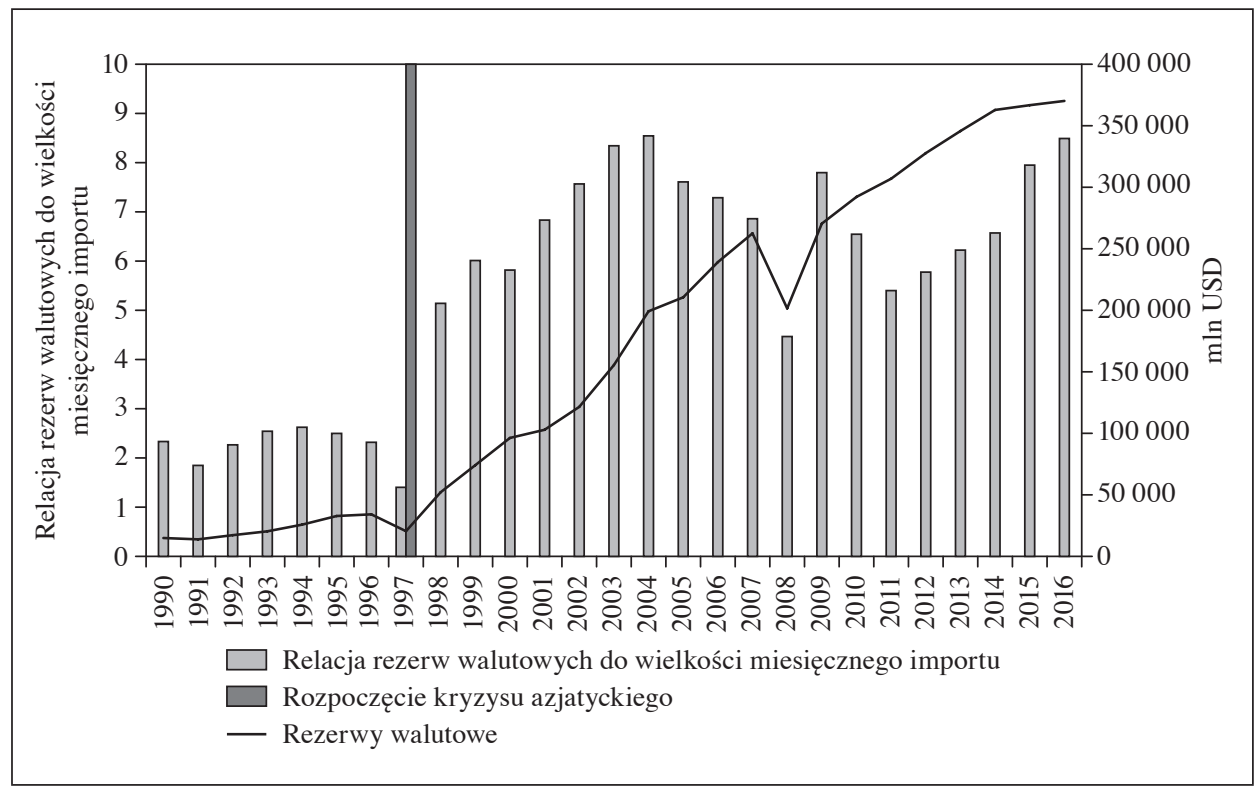

Rys. 1. Rezerwy walutowe Korei Południowej

Źródło: opracowanie własne na podstawie danych Banku Światowego, https://data.worldbank.org/ indicator/FI.RES.TOTL.CD?view=chart (data dostępu: 30.08.2017).

$\mathrm{Z}$ analizy działań podejmowanych przez banki centralne od upadku systemu z Bretton Woods wynika, że różne formy interwencji walutowych były dość często przeprowadzane. Jedne z najistotniejszych dla międzynarodowego systemu finansowego wiązały się z wdrożeniem porozumienia zawartego w hotelu Plaza w Nowym Jorku z 1985 r. (Plaza Accord lub Plaza Agreement). Zostało ono zawarte pomiędzy władzami amerykańskimi i władzami innych państw grupy G5. Działania te podjęto, ponieważ w ciągu pięciu lat poprzedzających rok podpisania porozumienia dolar umocnił się o $44 \%$ w stosunku do innych głównych walut, a w gospodarce USA wystąpił problem bliźniaczego deficytu (Frankel 2015, s. 1). W ciągu dwóch lat od zawarcia porozumienia wartość dolara spadła o 40\%. Działania wynikające z Plaza Accord stanowią przykład interwencji skoordynowanej.

Innym przykładem skoordynowanej interwencji walutowej były działania banków centralnych związane z silną deprecjacją euro w $2000 \mathrm{r}$. W analizowanym okresie wartość 1 euro była znacznie niższa od 1 dolara. W 2011 r. główne banki centralne na świecie wspólnie z Bankiem Japonii podjęły natomiast interwencję na rynku jena w celu ograniczenia jego aprecjacji, która wystąpiła po trzęsieniu ziemi i tsunami.

Opisane przykłady nie oznaczają, że banki centralne nie decydują się na unilateralne ingerencje na rynku waluty krajowej. W ostatnich latach działania 
takie podjął kilkukrotnie Narodowy Bank Polski. 9 kwietnia 2010 r. miała miejsce pierwsza interwencja walutowa NBP od momentu pełnego upłynnienia kursu w kwietniu 2000 r. (Polityka pieniężna 2011, s. 138). Miało to zapobiec nadmiernej aprecjacji złotego.

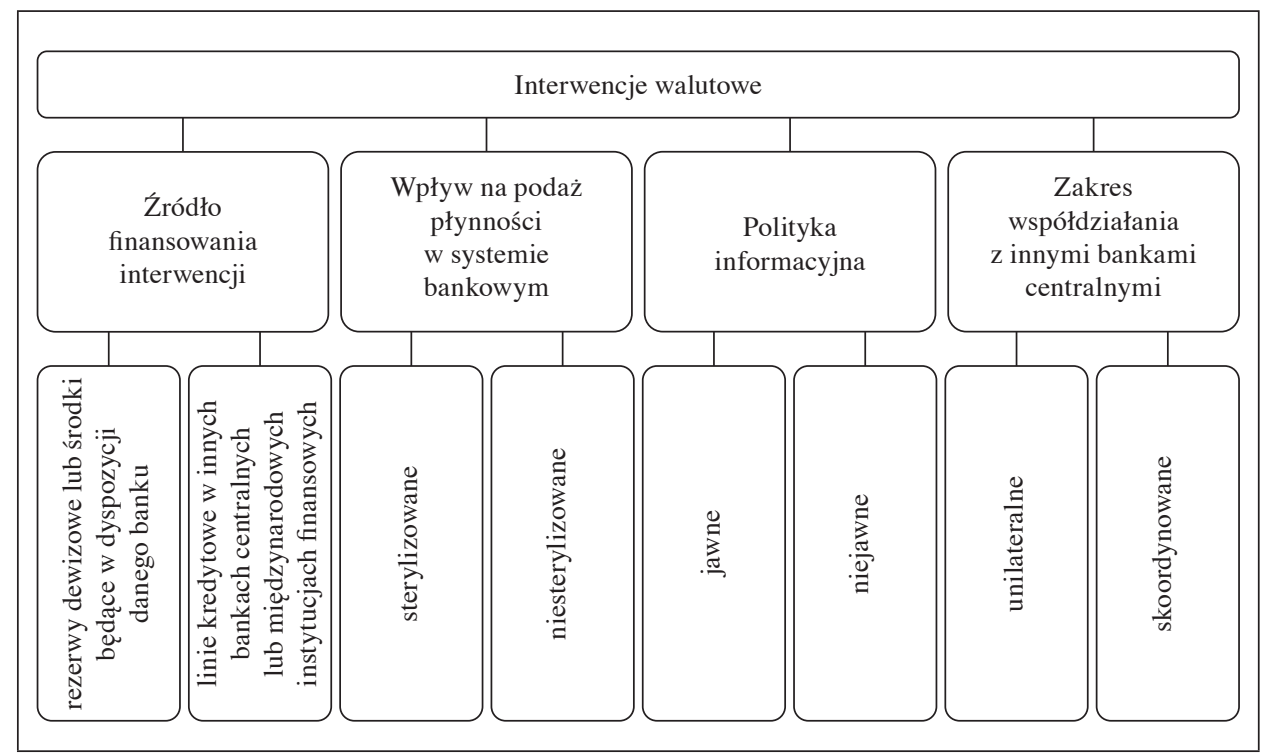

Rys. 2. Rodzaje interwencji walutowych banków centralnych

Źródło: opracowanie własne na podstawie (Karwowski 2011, s. 133-137).

W ostatnich latach aktywny na rynku waluty krajowej był również Szwajcarski Bank Narodowy. Począwszy od 2009 r., jego działania ukierunkowane są na ograniczenie skali aprecjacji franka szwajcarskiego. W ich rezultacie poziom relacji bilansu banku centralnego do PKB Szwajcarii przekroczył w 2016 r. 100\%. Co więcej, 93\% aktywów tego banku stanowią inwestycje w waluty obce, będące bezpośrednim rezultatem interwencji walutowych (109th Annual Report 2016, s. 78).

Ekonomiści nie są zgodni w kwestii skuteczności działań podejmowanych w ramach prowadzenia polityki kursu walutowego ${ }^{3}$. Większość z nich zgadza się jednak z tym, że niesterylizowane interwencje walutowe banku centralnego oddziałują na poziom kursu walutowego (Blanchard, Adler i de Carvalho Filho 2015, s. 3). Wynika to z występowania kanału monetarnego. W wypadku inter-

${ }^{3}$ Przegląd wyników badań dotyczących skuteczności wpływu interwencji walutowych na kształtowanie się kursu walutowego zawarto w publikacji (Sarno i Taylor 2001, s. 839-868). 
wencji sterylizowanych w literaturze przedmiotu opisywane są dwa kanały: portfelowy oraz sygnalizujący (sygnalny) (Sarno i Taylor 2001, s. 3) ${ }^{4}$.

Na podstawie analizy działalności banków centralnych J. Frankel (2015, s. 7) opracował listę okoliczności, których wystąpienie znacznie zwiększa prawdopodobieństwo powodzenia interwencji walutowej. Wśród nich można znaleźć następujące wskazówki:

- bank centralny nie powinien bronić kursu, który nie ma uzasadnienia makroekonomicznego,

- ważnym elementem interwencji jest zaskoczenie,

- działania interwencyjne powinny być przeprowadzane wspólnie przez kilka banków centralnych,

- informacje o interwencji powinny być podawane do publicznej wiadomości.

W dyskusji na temat skuteczności interwencji walutowych istotnych argumentów dostarczają także wyniki badań opublikowane w pracy (Blanchard, Adler i de Carvalho Filho 2015, s. 3). Autorzy potwierdzili, że kraje rozwijające się doświadczające znacznego napływu kapitału poprzez stosowanie interwencji walutowych były w stanie ograniczyć aprecjację waluty krajowej ${ }^{5}$.

$\mathrm{Z}$ interwencjami walutowymi związany jest problem polityki zubożania sąsiada oraz kwestia tzw. wojen walutowych, dlatego w 2013 r. państwa grupy G7 (Kanada, Francja, Niemcy, Włochy, Japonia, Wielka Brytania oraz USA) zdecydowały, że będą wstrzymywać się od interwencji walutowych (Statement... 2013). Zadeklarowano ponadto, że zmiany dokonywane w zakresie polityki monetarnej i fiskalnej będą miały na celu wyłącznie realizację polityki wewnętrznej, a nie wpływanie na kurs walutowy. Takie sformułowanie tej deklaracji wynika $\mathrm{z}$ wpływu pozostałych form polityki bilansu banku centralnego na kurs walutowy.

\section{Niekonwencjonalna polityka bilansu banku centralnego a kształtowanie się kursu walutowego}

W rezultacie działań antykryzysowych znacznie wzrosły sumy bilansowe oraz zmieniła się struktura bilansów banków centralnych. Na rys. 3 przedstawiono zmiany wielkości sumy bilansowej banku centralnego, spowodowane działaniami antykryzysowymi w USA oraz Japonii. Z analizy danych wynika, że w wypadku obu banków dochodziło do dynamicznych zmian. Przykład EBC potwierdza

${ }^{4}$ W literaturze przedmiotu wskazuje się także na możliwość wystąpienia kanałów: noise tradering oraz mikrostruktury rynku (zob. Polityka pieniężna 2011, s. 138).

5 Niektóre państwa rozwijające się zaczęły stosować interwencje walutowe mające ograniczyć deprecjację waluty krajowej, np. Chińska Republika Ludowa (zob. Wildau 2017). 
$\mathrm{z}$ kolei, że prowadzenie tego rodzaju polityki istotnie wpływa na strukturę bilansu banku (rys. 4 i 5).

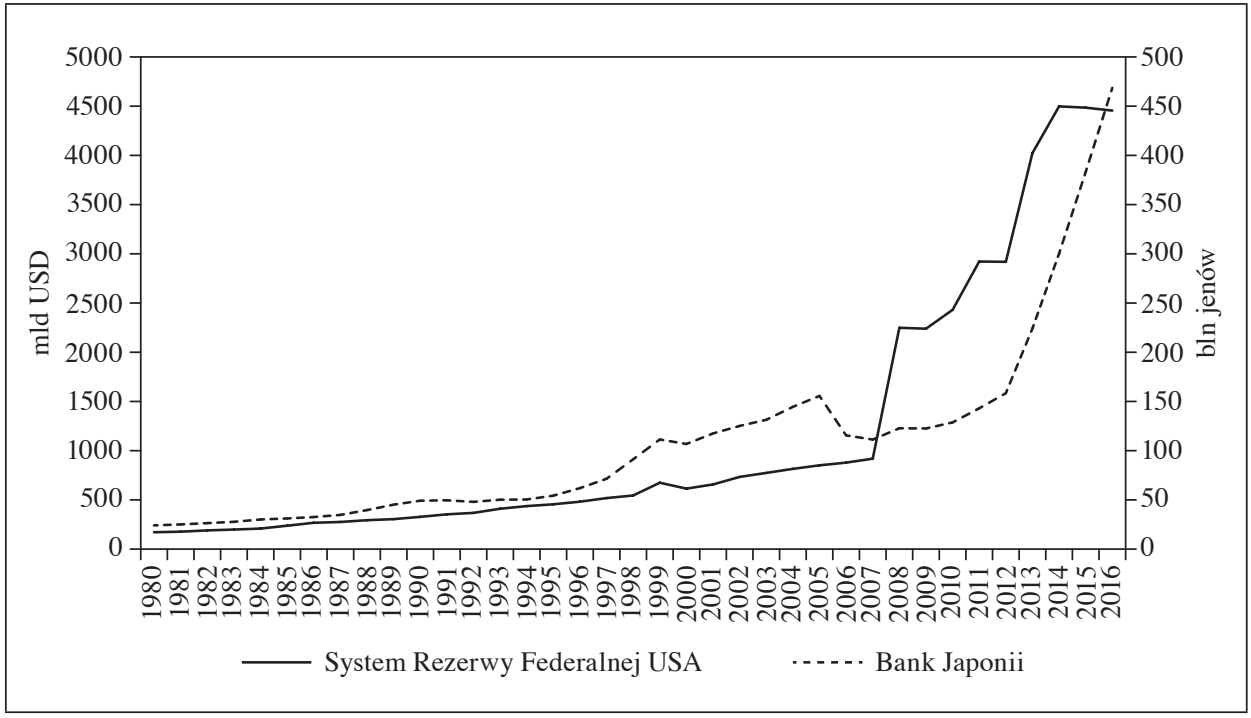

Rys. 3. Bilans Systemu Rezerwy Federalnej USA oraz Banku Japonii w latach 1980-2016

Źródło: opracowanie własne na podstawie danych opublikowanych na stronach: https://fred.stlouisfed.org/series/JPNASSETS, https://fred.stlouisfed.org/series/WALCL (data dostępu: 30.08.2017).

W celu ograniczenia skutków kryzysu finansowego System Rezerwy Federalnej USA, EBC, Bank Japonii oraz Bank Angliii ${ }^{6}$ wykorzystywały różnorodne programy, narzędzia dostarczania płynności. Z analizy podjętych działań wynika, że często prowadzono politykę bilansową. Przykładami quasi-zarządzania długiem publicznym są programy: Large Scale Asset Purchases (Systemu Rezerwy Federalnej USA) oraz Expanded Asset Purchase Programme (EBC). Polityka kredytowa została z kolei ujęta w działaniach takich jak: Quantitative and Qualitative Monetary Easing (QQE) with Yield Curve Control (Bank Japonii) oraz Asset Purchase Facility (Bank Anglii). Spośród niekonwencjonalnych działań w zakresie prowadzenia polityki bilansu w tym okresie najrzadziej odwoływano się do polityki rezerw bankowych. Ich oczekiwany poziom ustanowił Bank Anglii (Borio i Disyatat 2009, s. 17).

${ }^{6}$ Wyboru wymienionych banków centralnych dokonano ze względu na zakres wykorzystania przez nie niekonwencjonalnych instrumentów oraz znaczenie tych instytucji na międzynarodowych rynkach finansowych. 


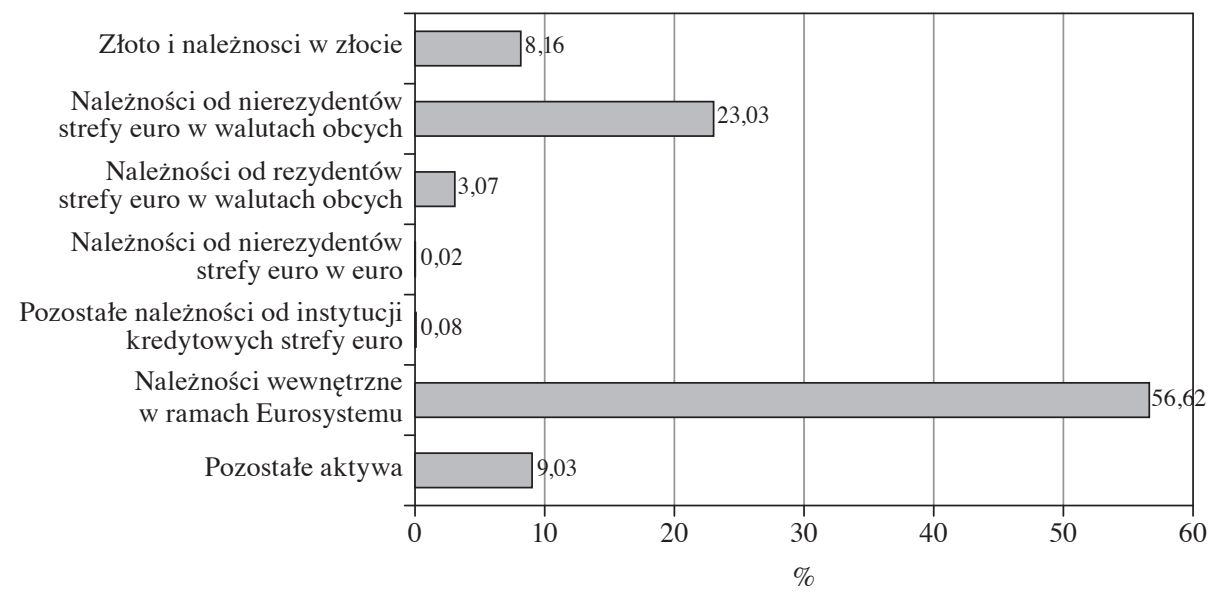

Rys. 4. Kompozycja bilansu EBC w 2007 r.

Źródło: opracowanie własne na podstawie raportu rocznego z 2007 r., Europejski Bank Centralny, s. 228, https://www.ecb.europa.eu/pub/pdf/annrep/ar2007pl.pdf?290e600f9cea7b425d57dc4cac8425d4 (data dostępu: 30.08.2017).

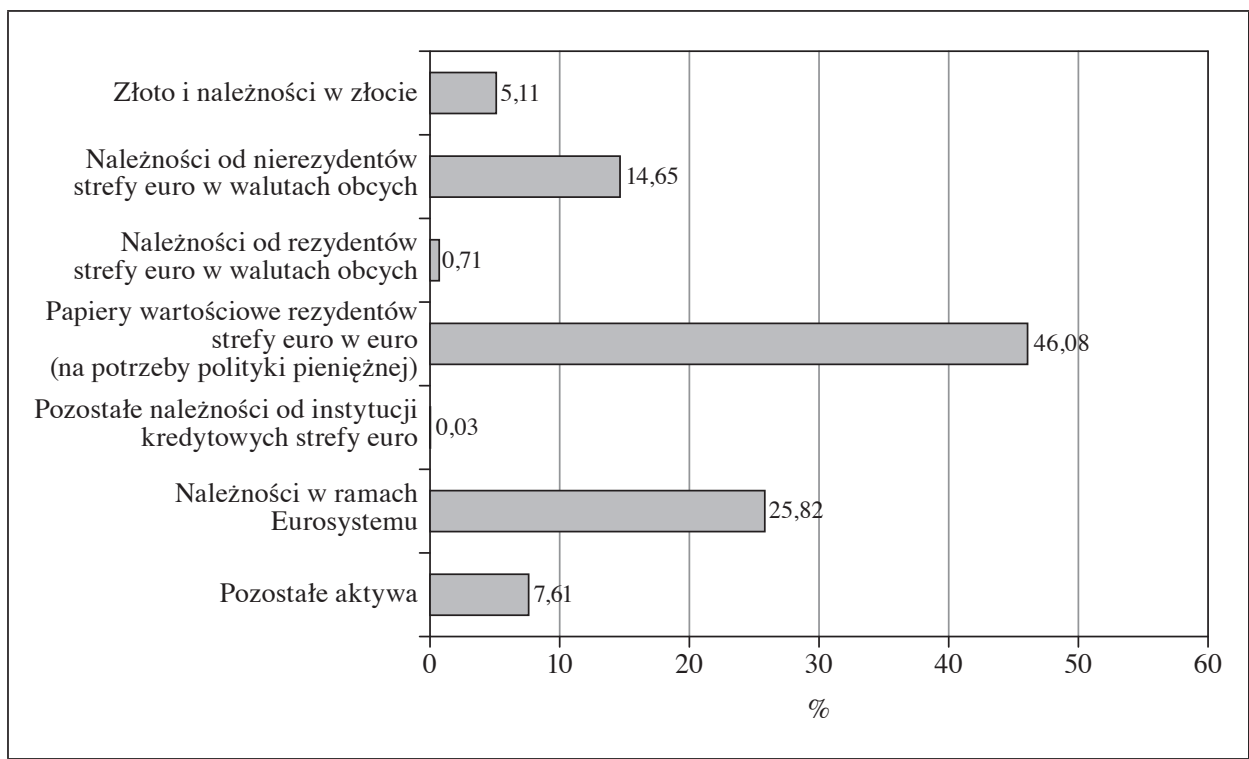

Rys. 5. Kompozycja bilansu EBC w 2016 r.

Źródło: opracowanie własne na podstawie raportu rocznego z 2016 r., Europejski Bank Centralny, s. 142, https://www.ecb.europa.eu/pub/pdf/annrep/ar2016pl.pdf?939e65cd47643e9a18694ee7b78fe088 (data dostępu: 30.08.2017). 
W dyskusji dotyczącej roli kursu walutowego w niekonwencjonalnej polityce bilansu istotne są trzy kwestie: jaką rolę przypisywano kursowi walutowemu podczas antykryzysowych działań w ramach polityki bilansu, jakie kanały oddziaływania polityki bilansu na kurs walutowy są rozpatrywane w teorii oraz jakie efekty mogą przynieść takie działania.

M. Krawczyk (2013, s. 481) wśród zalecanych przez niektórych ekonomistów rozwiązań mających na celu wydostanie się z pułapki płynności wymienia m.in. dewaluację krajowej waluty. Do badaczy uznających takie działania za słuszne należą: B. Bernanke, A.H. Meltzer, B.T. McCallum, L.E.O. Svensson, A. Orphanides oraz V. Wieland (zob. Svensson 2003, s. 12). Deprecjacja waluty krajowej pobudza gospodarkę poprzez zwiększenie eksportu oraz wzmocnienie sektorów konkurujących z importem (Svensson 2003, s. 12). Zmiany kursu walutowego są ponadto odnotowywane każdego dnia (Rzońca 2014, s. 274), a wskaźniki zmiany poziomu cen są publikowane znacznie rzadziej, kurs walutowy może więc mieć znacznie większy wpływ na kształtowanie oczekiwań inflacyjnych niż miary inflacji. W opinii L.E.O. Svenssona (2003, s. 13) bieżący kurs walutowy jest natychmiastowym sygnałem tego, czy zastosowane instrumenty pozwolą wydostać się z pułapki płynności.

W kontekście wydarzeń związanych z kryzysem najważniejsze jest jednak stanowisko byłego prezesa Systemu Rezerwy Federalnej USA B. Bernankego, a więc osoby, która kierowała największym bankiem centralnym na świecie w latach 2006-2014. E.S. Harris (2009, s. 166) zwrócił uwagę na to, że agresywne osłabianie dolara w celu podniesienia cen towarów importowanych stanowiło jeden z podstawowych elementów planu przeciwdziałania deflacji, który został ogłoszony przez B. Bernankego kilka lat przed nadejściem kryzysu. Wnioski takie B. Bernanke wyciągnął na podstawie analizy sytuacji panującej podczas wielkiego kryzysu lat 30. Według niego najskuteczniejszym antykryzysowym (antydeflacyjnym) działaniem F.D. Roosevelta oprócz zmian w systemie bankowym była właśnie dewaluacja dolara (Bernanke 2000, s. 25). Wspólnie z H. Jamesem przeprowadził badania związku pomiędzy porzucaniem standardu złota przez poszczególne państwa w latach 30. XX w. a siłą deflacji i recesji, których one doświadczyły (Bernanke i James 1991, s. 13). Stwierdził, że im dłuższy jest okres powstrzymywania dewaluacji, tym recesja jest mocniej odczuwana.

Obniżanie wartości waluty krajowej ma zatem być narzędziem przeciwdziałania deflacji oraz kryzysowi. Jednym z środków wykorzystywanych do kształtowania kursu walutowego jest prowadzenie niekonwencjonalnej polityki bilansu - takiej, w wypadku której nie uwzględnia się polityki kursu walutowego. Jej znaczenie dla osiągnięcia tego celu rośnie w sytuacji, gdy wartość stóp procentowych jest zbliżona do zera. W opinii L.E.O. Svenssona (2000, s. 6) zależność ta świadczy o tym, że skuteczność deprecjacji waluty krajowej z wykorzystaniem 
interwencji walutowych (rozwiązania zalecanego przez B.T. McCalluma) jest wątpliwa.

W teorii ekonomii opisuje się kilka kanałów transmisji polityki bilansu, które są rozpatrywane w kontekście wpływu niekonwencjonalnej polityki bilansu banku centralnego na poziom kursu walutowego. W wykładzie na temat polityki pieniężnej w Japonii w latach 90. A.H. Meltzer (2001, s. 20) podkreślał, że kurs walutowy reaguje na zmiany w podaży pieniądza. Rekomendował on rozwiązanie polegające na zwiększeniu bazy monetarnej, co skutkowałoby deprecjacją jena. Jest to przykład monetarnego kanału oddziaływania na kurs walutowy?

Ze względu na specyfikę pułapki płynności, rozważając możliwe kanały transmisji polityki bilansu, ekonomiści zwracają uwagę na kanał portfelowy - bank centralny, nabywając aktywa finansowe, zmienia ich podaż netto i wpływa tym samym na ich cenę. Jak zauważyli C. Borio oraz P. Disyatat (2009, s. 21), jest on najważniejszym kanałem opisywanym w literaturze dotyczącej kształtowania się kursu walutowego. A. Orphanides i V. Wieland (1999, s. 4) uznali efekt portfelowy za decydujący o wpływie zmiany bazy monetarnej na kurs walutowy. Zakłada się, że kurs zmienia się pod wpływem względnej zmiany w podaży pieniądza w kraju i za granicą. W rezultacie może dojść do utrzymywania się sytuacji, w której kurs walutowy kształtuje się niezgodnie z teorią niezabezpieczonego parytetu stóp procentowych.

Kolejnym kanałem oddziaływania polityki bilansu jest kanał sygnalizacyjny (signaling channel). Zgodnie $\mathrm{z}$ opisem tego kanału zawartym w publikacji M.D. Bauera oraz G.D. Rudebuscha (2013) komunikaty dotyczące stosowania ekspansywnej polityki bilansowej wpływają na obniżenie oczekiwanej przez podmioty gospodarcze przyszłej stopy procentowej, wydłużony zostaje oczekiwany okres ekspansji monetarnej. Dzieje się tak dlatego, że komunikat taki niesie z sobą informację na temat oceny bieżącej oraz przyszłej sytuacji gospodarczej banku centralnego, podmioty gospodarcze dostosowują więc swoje oczekiwania do uzyskanej w ten sposób informacji.

Znaczenie kanału sygnalnego wzrasta, jeżeli weźmie się pod uwagę zjawisko carry trade - jest to krótkoterminowa transakcja polegająca na „zaciągnięciu pożyczki w walucie nisko oprocentowanej i zakupie waluty wyżej oprocentowanej" (Polityka pieniężna 2011, s. 177-178). Największe ryzyko w wypadku takiej strategii jest związane z możliwością nagłej deprecjacji wyżej oprocentowanej waluty (crash risk). W sytuacji, gdy poprzez ekspansywną politykę bilansu do podmiotów gospodarczych (w tym inwestorów) wysyłane są sygnały dotyczące przyszłej polityki banków centralnych, ryzyko to ulega znacznemu zmniejszeniu. Strategia carry trade staje się więc bardziej atrakcyjna dla inwestorów. Wpływa to

${ }^{7}$ Niektórzy ekonomiści są zdania, że rezultatem wystąpienia zjawiska pułapki płynności może być niesprawność kanału monetarnego (zob. Svensson 2000, s. 5). 
niewątpliwie na zwiększenie presji deprecjacyjnej w odniesieniu do waluty kraju stosującego politykę bilansu.

W ostatnich latach w teorii kanałów transmisji polityki pieniężnej coraz większe znaczenie przypisuje się także kanałowi podejmowania ryzyka (Diamond i Rajan 2009). Polityka banku centralnego wpływa bezpośrednio i pośrednio na poziom podejmowanego przez banki (instytucje finansowe) ryzyka. Można wyróżnić trzy przyczyny takiej zależności (Demchuk i in. 2011, s. 11-12):

1. Polityka banku centralnego wpływa na sposób wyceny ryzyka przez instytucje finansowe.

2. Na rynku działają instytucje finansowe, które ustalają sztywne nominalne stopy zwrotu. Ekspansywna polityka pieniężna zmniejsza rentowność aktywów uważanych za wolne od ryzyka. Inwestorzy wybierają więc aktywa wiążące się z większym ryzykiem, ale pozwalające osiągnąć wyższe stopy zwrotu.

3. Większa przewidywalność banku centralnego w zakresie prowadzonej polityki zmniejsza niepewność na rynku, instytucje finansowe są więc bardziej skłonne do podejmowania innego rodzaju ryzyka. Zależność ta wynika z założenia, że dany podmiot charakteryzuje się stałym poziomem akceptacji ryzyka, a więc redukcja ryzyka związanego z polityką pieniężną skutkuje podjęciem większego ryzyka w innym obszarze.

W kontekście oddziaływania polityki bilansu na poziom kursu walutowego kanał podejmowania ryzyka ma znaczenie w sytuacji, gdy kraj stosujący ekspansję monetarną jest rozwinięty (co wiąże się z relatywnie niższym poziomem ryzyka), a partnerem jest państwo rozwijające się (a więc poziom ryzyka jest relatywnie wyższy). Rezultatem jest większy popyt na aktywa denominowane w walucie kraju rozwijającego się. Dyskusja na temat tego kanału nabiera znaczenia również w związku z wynikami badań M. Hattoriego, A. Schrimpfa oraz V. Sushki (2013), zgodnie z którymi skup aktywów przez System Rezerwy Federalnej USA oraz zapowiedzi takich działań istotnie wpłynęły na obniżenie poziomu postrzeganego ryzyka związanego z inwestowaniem na amerykańskim rynku finansowym.

Jeśli chodzi o efekty, jakie przynosi deprecjacja waluty krajowej w wyniku ekspansywnej polityki bilansowej, najbardziej ożywiona dyskusja dotyczy problemu polityki zubożania sąsiada (beggar-thy-neighbour policy). Według J. Robinson celowe obniżanie wartości waluty krajowej jest jednym z czterech sposobów prowadzenia tej polityki (Robinson 1979, cyt. za: Rzońca 2014, s. 275). „Zubożanie sąsiada” odbywa się na skutek poprawy konkurencyjności cenowej krajowego sektora eksportowego oraz konkurującego z importem, co prowadzi do osłabienia pozycji przedsiębiorstw i gospodarki innego kraju. W ten sposób recesja oraz deflacja są ,eksportowane” poza kraj prowadzący tego rodzaju politykę.

Sytuację, w której państwa zaczynają podejmować działania mające na celu obniżanie wartości walut innych państw, określa się mianem wojny walutowej. 
Według J. Rickardsa (2012, s. 61-93) w historii gospodarczej świata można wyróżnić trzy okresy prowadzenia przez państwa wojen walutowych. Pierwsza miała miejsce w latach 1921-1936, kolejna rozpoczęła się w 1967 r., a zakończyła w 1987 r. Za początkową datę rozpoczęcia trzeciej wojny walutowej przyjmuje się natomiast datę wypowiedzi brazylijskiego ministra finansów G. Mantegi (we wrześniu 2010 r. stwierdził on, że globalna wojna walutowa została rozpoczęta). W opinii J. Rickardsa (2012, s. 114) deklaracja ta została sformułowana, ponieważ w konsekwencji umocnienia się reala w stosunku do dolara w okresie zaledwie dwóch lat nastąpiło przejście od 15 mld USD nadwyżki handlowej Brazylii z USA (w 2009 r.) do deficytu wynoszącego 6 mld USD.

Według niektórych ekonomistów nie można jednak określać ekspansji monetarnej mającej swoje uzasadnienie w wewnętrznej sytuacji gospodarczej danego kraju mianem manipulowania walutą (Frankel 2015, s. 13). J. Frankel zwrócił uwagę na to, że w przeciwieństwie do sterylizowanych interwencji walutowych spadek wartości waluty krajowej wynikający z ekspansji monetarnej nie oddziałuje negatywnie na partnerów handlowych, ponieważ stymulowany przez politykę pieniężną, wzrost wydatków skutkuje zwiększeniem importu. Autor ten zauważa również, że państwa mogą zapobiegać aprecjacji waluty, stosując akomodacyjną politykę bilansu banku centralnego (w jej różnych formach). Takie rozwiązanie, w jego opinii, powinno skutkować globalną ekspansją monetarną, która jest konieczna w okresach kryzysów.

Wyniki badań opublikowane w pracy (Blanchard, Adler i de Carvalho Filho 2015) pozwoliły potwierdzić hipotezę o wysokiej skuteczności interwencji walutowych mających na celu ograniczenie presji aprecjacyjnej wynikającej z napływu kapitału zagranicznego. Skala płynności wygenerowanej przez największe banki centralne gospodarek rozwiniętych (rys. 6) jest jednak źródłem kolejnego problemu związanego z zarządzaniem historycznie dużymi rezerwami walutowymi powstałymi w wyniku tych transakcji.

Zwrócono już wcześniej w artykule uwagę na problem wpływu ekspansywnej polityki bilansu banku centralnego na poziom kursów walutowych krajów rozwijających się. W ostatnich latach okazało się, że może ona oddziaływać również na poziom zmienności, jaki występuje na rynku walutowym tych krajów. Wynika to w dużej mierze ze spekulacyjnego charakteru napływającego kapitału. Kraje te były szczególnie narażone na wystąpienie tego problemu w okresie od maja do września 2013 r. z uwagi na zapowiedzi ograniczenia skali ekspansji pieniężnej przez System Rezerwy Federalnej USA.

Zagadnienia dotyczące wpływu polityki bilansu EBC oraz Systemu Rezerwy Federalnej USA na zmienność występującą na rynkach krajów rozwijających się rozważali także A. Apostolou oraz J. Beirne (2017). Przeprowadzili oni badania na próbie obejmującej 13 krajów (w tym Polskę), z których wynika, że zmiany 


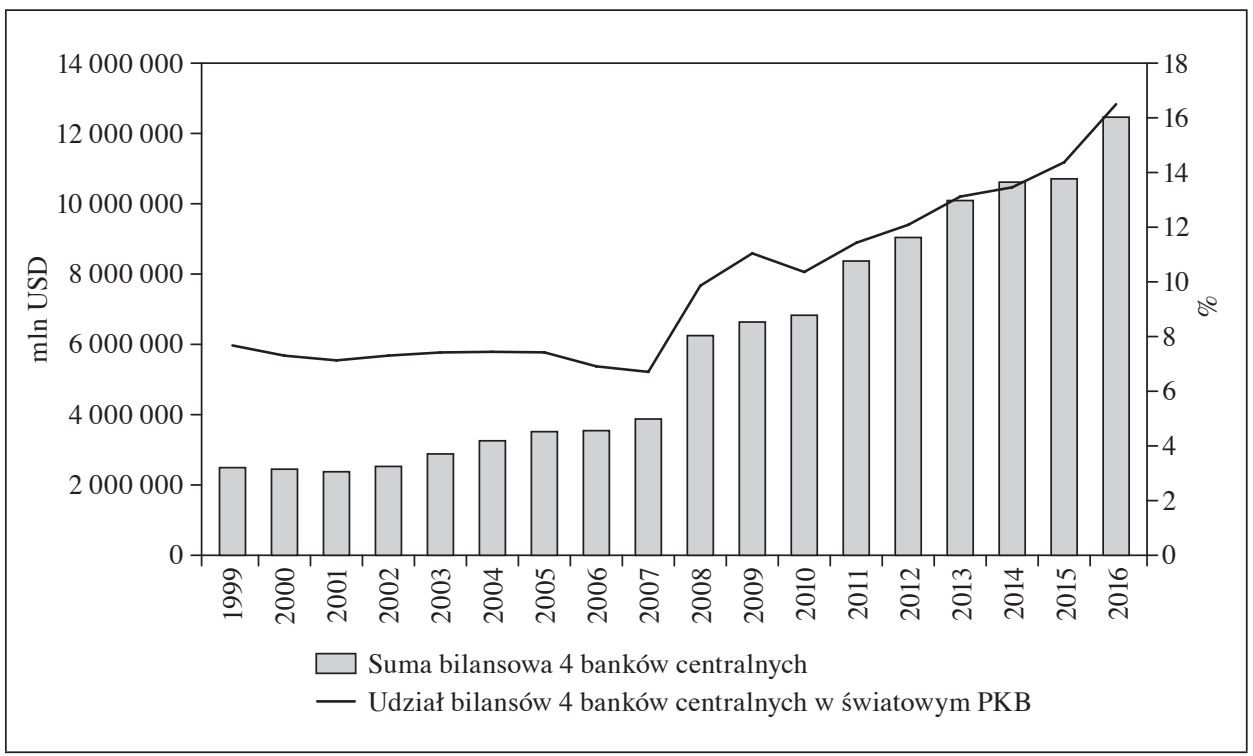

Rys. 6. Bilanse banków centralnych (Systemu Rezerwy Federalnej USA, Banku Japonii, Banku Anglii oraz EBC) w relacji do globalnego PKB w latach 1999-2016

Źródło: opracowanie własne na podstawie danych opublikowanych na stronach https://fred.stlouisfed.org/series/JPNASSETS, https://fred.stlouisfed.org/series/WALCL, https://fred.stlouisfed.org/ series/UKASSETS, https://fred.stlouisfed.org/series/ECBASSETS, https://data.worldbank.org/indicator/NY.GDP.MKTP.CD (data dostępu: 30.08.2017).

w poziomie bilansu wpływają na zmienność bilateralnego kursu walutowego: im większe zmiany następują w bilansie, tym wyższa jest zmienność kursu walutowego. Co więcej, efekt spillover jest znacznie silniejszy w wypadku polityki bilansu prowadzonej przez System Rezerwy Federalnej USA. Autorzy nie udowodnili, że efekt ten wpłynął na zmienne gospodarki realnej badanych krajów rozwijających się. Nie oznacza to jednak, że zwiększona zmienność kursu walutowego nie będzie mieć negatywnego wpływu na wzrost gospodarczy w tych państwach ${ }^{8}$.

\section{Podsumowanie}

Polityka bilansu banku centralnego stanowiła podstawowe narzędzie do przeciwdziałania przez banki centralne skutkom kryzysu subprime. Jak wynika

${ }^{8} \mathrm{Na}$ silną negatywną relację pomiędzy zmiennością kursu walutowego a wzrostem gospodarczym wskazał G. Schnabl (2007). 
z przedstawionej w artykule analizy, kurs walutowy odgrywa w niej istotną rolę. Co więcej, nie ogranicza się ona wyłącznie do polityki kursu walutowego, lecz obejmuje również pozostałe formy polityki bilansu. Uzyskuje to potwierdzenie zarówno w pracach teoretycznych, jak i w działaniach banków centralnych prowadzonych w okresie wielkiej recesji. W literaturze przedmiotu kurs walutowy jest niejednokrotnie wymieniany jako narzędzie pozwalające uniknąć pułapki płynności. Prowadzenie przez bank centralny polityki bilansu pozwala więc w dużym stopniu wpływać na poziom kursu walutowego i dzięki temu osiągać inne cele o charakterze makroekonomicznym.

$\mathrm{Z}$ wykorzystaniem kursu walutowego w polityce bilansu wiążą się jednak pewne kontrowersyjne kwestie, takie jak: polityka zubożania sąsiada oraz wojny walutowe. Co więcej, z najnowszych badań wynika, że skupowanie aktywów przez bank centralny wpływa również na poziom zmienności kursu walutowego, a tym samym w wypadku niektórych państw może ograniczać wzrost gospodarczy. W kontekście tzw. strategii wyjścia znaczenie kursu walutowego w polityce bilansu z pewnością będzie przedmiotem dalszych badań.

\section{Literatura}

109th Annual Report (2016), Swiss National Bank, https://www.snb.ch/en/mmr/reference/annrep_2016_komplett/source/annrep_2016_komplett.en.pdf (data dostępu: 30.08.2017).

Apostolou A., Beirne J. (2017), Volatility Spillovers of Federal Reserve and ECB Balance Sheet Expansions to Emerging Market Economies, ECB Working Paper Series No 2044, Frankfurt am Main.

Bauer M.D., Rudebusch G. (2013), The Signaling Channel for Federal Reserve Bond Purchases, Federal Reserve Bank of San Francisco Working Paper Series 2011-21.

Bernanke B. (2000), Japanese Monetary Policy: A Case of Self-induced Paralysis? Presentation at the ASSA meeting, January 9, Boston, https://www.princeton.edu/ $\sim$ pkrugman/bernanke_paralysis.pdf (data dostępu: 30.08.2017).

Bernanke B. (2005), The Global Saving Glut and the U.S. Current Account Deficit, speech at the Homer Jones Lecture, April 14, St. Louis, Missouri, https://www.federalreserve.gov/boarddocs/speeches/2005/200503102/ (data dostępu: 30.08.2017).

Bernanke B. (2015), Why Are Interest Rates So Low, part 3: The Global Savings Glut, „Brookings”, April 1.

Bernanke B., James H. (1991), The Gold Standard, Deflation, and Financial Crisis in the Great Depression: An International Comparison (w:) Financial Markets and Financial Crises, red. R.G. Hubbard, University of Chicago Press, Chicago.

Blanchard O., Adler G., de Carvalho Filho I. (2015), Can Foreign Exchange Intervention Stem Exchange Rate Pressures from Global Capital Flow Shocks? NBER Working Paper No 21427, Cambridge, MA, https://doi.org/10.3386/w21427.

Borio C., Disyatat P. (2009), Unconventional Monetary Policies: An Appraisal, BIS Working Papers No 292, Basel, https://doi.org/10.2139/ssrn.1541243. 
Borio C., Disyatat P. (2011), Global Imbalances and the Financial Crisis: Link or no Link? BIS Working Papers No 346, Basel, https://doi.org/10.2139/ssrn.1859410.

Borio C., Gabriele G., Heath A. (2008), FX Reserve Management: Trends and Challenges, BIS Papers No 40, Basel.

Brunet A., Guichard J.P. (2011), Chiny światowym hegemonem? Imperializm ekonomiczny Państwa Środka, Wydawnictwo Studio Emka, Warszawa.

Demchuk O., Łyziak T., Przystupa J., Sznajderska A., Wróbel E. (2011), Mechanizm transmisji polityki pieniężnej w Polsce. Co wiemy w 2011 roku?, Insty tut EkonomicznyNarodowy Bank Polski, Warszawa.

Diamond D., Rajan R. (2009), Illiquidity and Interest Rate Policy, NBER Working Paper Series No 15197, Cambridge, MA, https://doi.org/10.3386/w15197.

Frankel J.A. (2014), Why the ECB Should Buy American, Project Syndicate. The World's Opinion Page, March 13, https://www.project-syndicate.org/commentary/jeffrey-frankel-urges-the-ecb-to-buy-us-treasuries-to-expand-the-monetary-base?barrier=accessreg (data dostępu: 30.08.2017).

Frankel J.A. (2015), The Plaza Accord, 30 Years Later, NBER Working Paper Series No 21813, Cambridge, MA, https://doi.org/10.3386/w21813.

Harris E.S. (2009), Fed Bena Bernanke. Bank Rezerwy Federalnej po Greenspanie, Wydawnictwo Studio Emka, Warszawa.

Hattori M., Schrimpf A., Sushko V. (2013), The Response of Tail Risk Perceptions to Unconventional Monetary Policy, BIS Working Papers No 425, Basel, https://doi. org/10.2139/ssrn.2566769.

Karwowski J. (2011), Interwencje na rynku walutowym (w:) Polityka pieniężna, red. A. Sławiński, C.H. Beck, Warszawa.

Kimura T., Small D. (2004), Quantitative Monetary Easing and Risk in Financial Asset Markets, FEDS Working Paper No 2004-57, Washington, DC, https://doi.org/10.2139/ ssrn.633201.

Krawczyk M. (2013), O polityce fiskalnej i pieniężnej w warunkach pułapki płynności, „Ekonomista”, nr 4.

Meltzer A.H. (2001), Monetary Transmission at Low Inflation: Some Clues from Japan in the 1990s, „Monetary and Economic Studies”, vol. 19(S1), February.

Mohanty M.S. (2013), Market Volatility and Foreign Exchange Intervention in EMEs: What Has Changed? BIS Papers No 73: Volatility and Foreign Exchange Intervention in EMEs: What Has Changed?, Monetary and Economic Department, Basel.

Moreno R. (2005), Motives for Intervention, BIS Papers No 24: Foreign Exchange Market Intervention in Emerging Markets: Motives, Techniques and Implications, Monetary and Economic Department, Basel, https://doi.org/10.2139/ssrn.1188513.

Orphanides A., Wieland V. (1999), Efficient Monetary Policy Design near Price Stability, Board of Governors of the Federal Reserve System Working Paper, December, https://www.federalreserve.gov/pubs/feds/1999/199967/199967pap.pdf (data dostępu: 30.08.2017).

Polityka pieniężna (2011), red. A. Sławiński, C.H. Beck, Warszawa.

Rickards J. (2012), Wojny walutowe. Nadejście kolejnego globalnego kryzysu, Onepress, Gliwice.

Rzońca A. (2014), Kryzys banków centralnych. Skutki stopy procentowej bliskiej zera, C.H. Beck, Warszawa. 
Sarno L., Taylor M.P. (2001), Official Intervention in the Foreign Exchange Market: Is It Effective and, If So, How Does It Work?, „Journal of Economic Literature”, vol. 39, nr 3, https://doi.org/10.1257/jel.39.3.839.

Schnabl G. (2007), Exchange Rate Volatility and Growth in Small Open Economies at the EMU Periphery, ECB Working Paper Series No 773, Frankfurt am Main, https://doi. org/10.2139/ssrn.955250.

Smaghi L.B. (2009), Conventional and Unconventional Monetary Policy, keynote lecture at the International Center for Monetary and Banking Studies, April 28, Geneva, https://www.ecb.europa.eu/press/key/date/2009/html/sp090428.en.html (data dostępu: 30.08.2017).

Statement by the G7 Finance Ministers and Central Bank Governors (2013), February 12, https://www.gov.uk/government/news/statement-by-the-g7-finance-ministers-and-central-bank-governors (data dostępu: 30.08.2017).

Svensson L.E.O. (2000), The Zero Bound in an Open Economy: A Foolproof Way of Escaping from a Liquidity Trap, NBER Working Paper Series No 7957, Cambridge, MA, https://doi.org/10.3386/w7957.

Svensson L.E.O. (2003), Escaping from Liquidity Trap and Deflation: The Foolproof Way and Others, NBER Working Paper Series No 10195, Cambridge, MA, https://doi. org/10.3386/w10195.

Twardosz A. (2013), The Influence of Global Imbalances on the Build-up of Current Financial Crisis, „Argumenta Oeconomica Cracoviensia”, nr 9, https://doi.org/ 10.15678/aoc.2013.0903.

Wildau G. (2017), China Central Bank Intervention Pushes Renminbi to 6-month High, „Financial Times”, June 1, https://www.ft.com/content/b606023a-468c-11e7-85199f94ee97d996 (data dostępu: 30.08.2017).

Xie Y., Wong A. (2015), Once over \$12 Trillion, the World's Currency Reserves are Now Shrinking, „Bloomberg”, 6 kwietnia, https:/www.bloomberg.com/news/articles/2015-04-05/once-over-12-trillion-the-world-s-reserves-are-now-shrinking (data dostępu: 30.08.2017).

\section{Central Bank Balance Sheet Policy and the Exchange Rate}

(Abstract)

The financial crisis that began on the American real estate market has resulted in significant changes in monetary policy, one of the most important of which is policy governing central bank balance sheets, in which the exchange rate plays an important role. The article presents a classification of central bank balance sheet policy, considering the significance of the exchange rate in the various forms of this policy. The study includes an overview of the literature analysing the role attributed to the exchange rate in conducting monetary policy based on shaping the size and structure of the balance sheet. It also presents the issues of channels through which balance sheet policy comes over to affect the exchange rate.

Keywords: central bank balance sheet policy, exchange rate, financial crisis, currency devaluation. 